\title{
Phenology of Daphnia in a Northern Italy pond during the weather anomalous 2014
}

\author{
Valeria ROSSI, ${ }^{1 *}$ Catia MAURONE, ${ }^{1}$ Giorgio BENASSI, ${ }^{1}$ Silvia MARKOVÁ,,${ }^{2}$ Petr KOTLÍK, ${ }^{2}$ Nicolò BELLIN,${ }^{1}$ \\ Ireneo FERRARI ${ }^{1}$
}

${ }^{1}$ University of Parma, Department of Life Sciences, Viale Usberti, 11/A 43124 Parma, Italy; ${ }^{2}$ Laboratory of Molecular Ecology, Institute of Animal Physiology and Genetics, Academy of Sciences of the Czech Republic, Rumburská 89, 27721 Liběchov, Czech Republic *Corresponding author: valeria.rossi@unipr.it

\begin{abstract}
This note reports a comparison between Daphnia phenology in the weather anomalous 2014 and a previous three years period (2011-2013), in a shallow water body of Northern Italy (Bodrio del pastore III) where we recorded D. pulex. In 2011-2013, Daphnia population showed 1-2 density peaks from mid spring to early summer, it declined in July-August and did not recover, from ephippia, until the following spring. The seasonal dynamics was probably related to the species thermal tolerance. Males and ephippial females appeared at the beginning of growth season according to a typical feature of Daphnia populations from temporary habitats. The presence of the Chaoborus larvae resulted in juvenile adaptive predator-avoidance cyclomorphosis. In 2014, in the study area, mean winter air temperature was much warmer than average recorded during the past three years while it was much colder than average in July and August. This reflected the relatively rainy and cloudy summer months: the winter and summer precipitations total was above the previous three years average. In 2014, Daphnia was found all over the year and showed a maximum peak of density in November. The general increase of Daphnia was related to a shift in D. pulex population phenology, seasonal growth started earlier and lasted longer, and to the occurrence of D. longispina. Both species were identified by genetic markers and phylogenetic analyses of ND5 sequences placed isolates from the Bodrio del pastore III into the European D. pulex group. Both populations reproduced by cyclical parthenogenesis and showed cyclomorphosis. However, D. pulex produced more males and ephippial females than D. longispina. Their seasonal dynamics were quite different: D. longispina dominated in late summer while D. pulex showed the highest density in November. The presence of D. pulex in the Bodrio is important in the framework of conservation ecology especially because we have showed that it is native European strain instead of the invasive North American clone that replaced native D. pulex throughout Africa and was already recorded in Italy. We provide some indications and discuss how Daphnia phenology of shallow lakes of temperate areas may be susceptible to inter-annual variability in weather conditions.
\end{abstract}

Key words: Interannual meteo-climatic variability; Daphnia pulex; D. longispina; recruitment from ephippia; shallow water.

Received: March 2015. Accepted: May 2015.

\section{INTRODUCTION}

Growing evidence for phenological changes of plankton in response to climate change come from empirical, experimental and theoretical research over recent years (Edward and Richardson, 2004; Winder and Schindler, 2004; Hays et al., 2005; Visser and Both, 2005; Richardson, 2008; Vadadi-Fülöp and Hufnagel, 2014). Zooplankton is a key component of aquatic food webs and the climate change may cause different adverse effects on species diversity by means of elimination of sensitive species, replacement of sensitive species/strains by less sensitive ones, shifts in food-web interactions; acclimation of species/strains to stress, selection of tolerant genotypes, outcome of predator-prey interactions by altering the ability of prey to detect predators or to implement defensive responses both in marine and freshwater habitats (Riessen et al., 2012; Vadadi-Fülöp et al., 2012; VadadiFülöp and Hufnagel, 2014). Shallow water bodies are highly sensitive to climate warming due to substantial changes in thermal and hydrological regimes; changes in phenology may be important to ecosystem function because the level of response may vary across functional groups and multiple trophic levels (Scheffer et al., 2001; Meerhoff et al., 2007; Feuchtmayr et al., 2009; Landkildehus et al., 2014).

In a previous paper we reported the occurrence of Daphnia pulex in a permanent water body, Bodrio del pastore III, in Northern Italy (Rossi et al., 2014). During a three year study (2011-2013), the dynamics of this population was characterised by an increase in density from spring to early summer, a decline in July-August and a recover, presumably from ephippia, only in the following spring (Fig. 1). The seasonal dynamics was probably related to the species thermal tolerance. Male and ephippial females appeared at the beginning of growth season, before the density peak, according to a typical feature of Daphnia populations from temporary habitats. The presence of the predaceous larvae of Chaoborus flavicans probably account for seasonal variation of juveniles morphology that showed neckteeth and/or elongated tail spines as typical predator- 
avoidance morphological traits (Rossi et al., 2014). Recently, the invasive hybrid lineage of the American D. pulex and American D. pulicaria, invaded Africa and was already recorded in Northern Italy and Sardinia (Mergeay et al., 2006; Fadda et al., 2011; Marková et al., 2013). In this study, we used a diagnostic mitochondrial DNA gene to identify if $D$. pulex population from Bodrio del pastore III represents this invasive hybrid clone or if it belongs to native European D. pulex strain. Moreover, in 2014 our survey continued with the aim of evaluating the role of $C$. flavicans larvae in the Daphnia population dynamics and cyclomorphosis (Rossi et al., 2014).

We are now reporting this note on the peculiar D. pulex phenology and on the occurrence of $D$. longispina in the weather anomalous 2014. The 2014 was the warmest year across global land and ocean surfaces since records began in 1880 (http://www.ncdc.noaa.gov/sotc/global/). The winter and summer precipitations total was above the $20^{\text {th }}$ century average, marking the wettest summer even recorded, and the wettest since 1989.

\section{METHODS}

The Bodrio del pastore III ( $28 \mathrm{~m}$ asl, $45^{\circ} 00^{\prime} 05^{\prime \prime} \mathrm{N}$ $10^{\circ} 19^{\prime} 26^{\prime \prime}$ E, Hayford ellipsoid) is a water body located in cultivated lands in Cremona province and originated by erosion and evorsion from the old Po river-bed surface. It is considered a permanent water body, it has a surface area of about $3130 \mathrm{~m}^{2}$, and a maximum depth of $6.30 \mathrm{~m}$. Its volume is affected by River Po level, aquifer, precipitation, runoff and river inundations (Rossi et al., 2014).

Bi-weekly surveys were carried out from March to December 2014 and zooplankton was collected by 105 $\mu \mathrm{m}$-mesh net. From 2 to $16 \mathrm{~L}$ of water were filtered for each sample according to the water volume and depth. Each sample was preserved in $95 \%$ ethanol. During each survey, water temperature was measured a few centime-

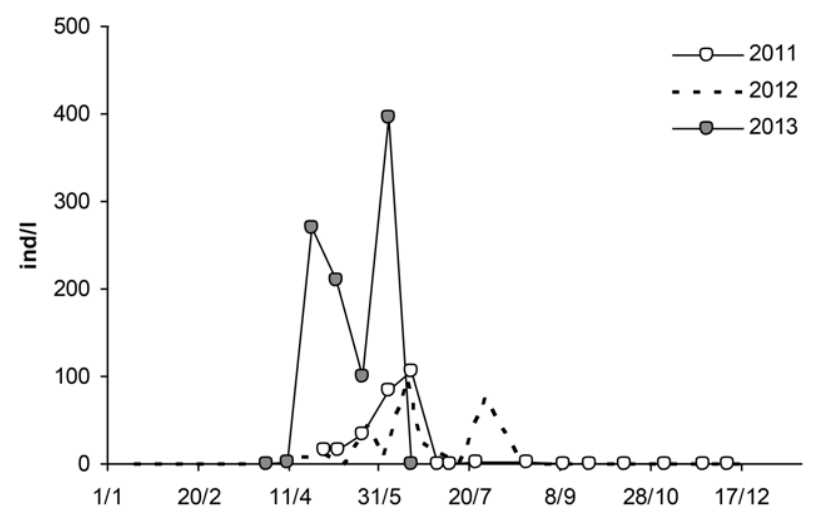

Fig. 1. Monthly variation of $D$. pulex total density in the period 2010-2013. tres below the surface and maximum depth was recorded. The water volume was estimated by considering the Bodrio conical shape according to the formula: $V=(S * h) / 3$ where $\mathrm{S}$ is the surface area and $\mathrm{h}$ is the maximum depth. Meteorological data about daily air temperature and rainfall were collected from the weather station LaCrosse WS2350 of Gussola.

To check the species identity of D. pulex from Bodrio del pastore III, a diagnostic mitochondrial DNA gene (sub-unit 5 of the NADH; ND5) was used to sequence 10 Daphnia isolates sampled in March, May and June. Total genomic DNA was extracted from Daphnia stored in 95\% ethanol using the QIAGEN DNeasy Tissue Kit (Valencia, CA). Approximately 711 bp long fragment of ND5 gene was amplified and sequenced in accordance with the PCR and sequencing conditions described by Dufresne et al. (2011). Additional data for the D. pulex complex were included from previously published sequences (Mergeay et al., 2006; Fadda et al., 2011; Marková et al., 2007, 2013). To check the species identity of different Daphnia species (namely D. longispina) diagnostic mitochondrial DNA gene (12S rRNA) was used for isolates sampled in March, May and June. Nucleotide sequence data from the present study have been deposited in the GenBank database (accession number KR233296). The maximum-likelihood tree was constructed using MEGA software ver. 6 (Tamura et al., 2013), and based on HKY+I nucleotide substitution model selected according to the Bayesian information criterion (BIC), with the base frequencies A, 0.19 ; C, 0.18; G, 0.21; T, 0.42; and the proportion of invariable sites equal to 0.490 . Bootstrap support was estimated from 1000 replicates.

Abundance of Daphnia was enumerated using 100\% of each sample and the number of juveniles, adult males, adult females, ovigerous females and ephippial females was recorded. In each sample, to check the morphological species identity, the analysis of at least 100 individuals was made and D. pulex was classified by the presence of the pecten on postabdominal claw (Margaritora, 1985). Individuals were classified, photographed and measured using a dissecting microscope and a stereomicroscope and the Nis-Elements D 3.1 software (NIKON NIS Elements Imaging Software).

\section{RESULTS}

In most 2014, mean monthly air temperatures were much warmer than average recorded during the past three years while they were much colder than average in July and August (Fig. 2). This likely reflected the relatively (wet) rainy and cloudy summer months acting to moderate temperatures. The winter and summer precipitations total was above the previous three years average. Abundant rainfall and the Po River flood accounted for the Bodrio volume that varied between $2380 \mathrm{~m}^{3}$ (October 24 $4^{\text {th }}$ ) 
and $4948 \mathrm{~m}^{3}$ (November $21^{\mathrm{st}}$ ). As in the previous three years the Daphnia population was probably re-established from resting eggs (Fig. 3), but in 2014 the annual peak densities varied substantially. Early seasonal peak was anticipated, with respect to the previous study period, to late winter and a second late spring peak was recorded just before a sharp population decrease in June-August: further bout of density and the maximum annual peak were recorded in late August and early November, respectively.

Totally 10 individuals from Bodrio del pastore III sampled in different periods of the year were used in phylogenetic analyses. Whereas the ND5 is a diagnostic mitochondrial gene for species from $D$. pulex complex and the ND5 oligonucleotide primers are specific for $D$. pulex group, only five isolates were amplified in PCR reaction and sequenced. Five isolates shared the same ND5 haplotype that clustered with European D. pulex clade (Fig. 4). The species identity for the additional five isolates was checked by sequencing the $12 \mathrm{~S}$ rRNA mitochondrial gene. The phylogenetic analyses placed all $12 \mathrm{~S}$ rRNA sequences within the D. longispina group (data will be published elsewhere).

In fact, in 2014, D. pulex coexisted with $D$. longispina and the population dynamics of the two species were quite different. At the beginning of the season both species were present in similar proportions while different percentage of $D$. pulex and $D$. longispina were responsible of the density increase of Daphnia population later on $\left(\chi^{2}=273\right.$, df $=9, \mathrm{P}<0.01$ ) (Fig. 3). However, it is important to note that in May and June the accurate morphological discrimination of D. pulex and D. longispina isolates was prevented by the presence of epibionts on the postabdominal claw of most individuals. For this reason the percentage of different species in spring samples may be not completely reliable. D. pulex and D. longispina coexistence was confirmed by genetic analyses of Daphnia isolates sampled in March, May and June 2014. D. pulex disappeared in July and August, reappeared in September and in November when became dominant being the major responsible of the highest annual density peak. D. longispina was recorded throughout all the sampling period, with the exception of April 24 $4^{\text {th }}$ (only two individuals were recorded on July $27^{\text {th }}$ and August $7^{\text {th }}$ ) and showed the highest densities at the end of August.

Males were recorded throughout all the sampling period, with the exception of April $24^{\text {th }}$, July, August $7^{\text {th }}$, September $28^{\text {th }}$ and October $24^{\text {th }}$. Density of adult and juveniles males was between 0.2 and 139 ind $\mathrm{L}^{-1}$, on June $20^{\text {th }}$ and November $9^{\text {th }}$, respectively. Free ephippia and/or ephippial females were also recorded throughout all the

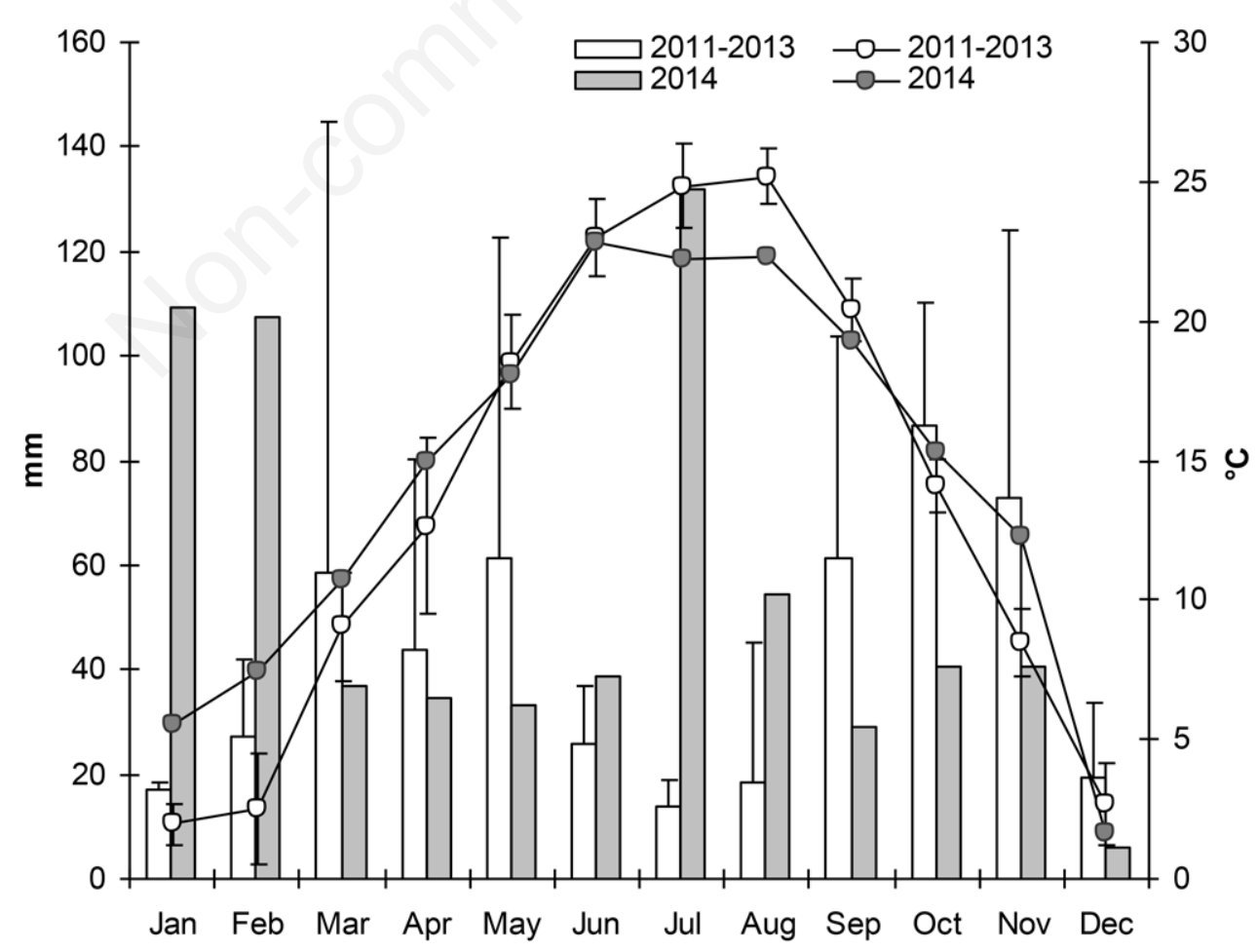

Fig. 2. Monthly variation of rainfall and air temperatures in 2014 and mean values (with standard deviation) recorded during the period 2011-2013 in the sampling area. 
sampling period with the exception of July $4^{\text {th }}$ and September. Their densities were between 0.3 and 19 ind $\mathrm{L}^{-1}$, on August $28^{\text {th }}$ and November $21^{\text {st }}$, respectively. Male and ephippial females frequencies were mainly supported by D. pulex with $95 \%$ of total males and $87 \%$ of total ephippial females. The highest densities of $D$. longispina males and ephippial females were recorded on August $28^{\text {th }}$ (2.29 ind $\left.\mathrm{L}^{-1}\right)$ and November $9^{\text {th }}\left(3.67\right.$ ind $\left.\mathrm{L}^{-1}\right)$, respectively.

Chaoborus flavicans larvae were found in 5 samples (March $30^{\text {th }}$, April $10^{\text {th }}$, May $9^{\text {th }}$, August $28^{\text {th }}$ and September $28^{\text {th }}$ ) and their density was near or below 1 ind $\mathrm{L}^{-1}$. Seasonal variation was recorded in the frequency of Daphnia, most juveniles, showing neckteeth on the dorsal part of the carapace (Fig. 3). Most juveniles of both $D$. pulex and D. longispina showed neckteeth through March and May. Percentage of individuals with the typical predator-avoidance morphological trait decreased in June and most Daphnia juveniles did not show neckteeth in late autumnal samples.

\section{DISCUSSION}

The global anomaly of weather in 2014 was confirmed by our local data on mean air temperature and on precipitations. In general, mean air temperatures were the highest in the last three years and the winter and summer precipitations was above the 2011-13 years average, making July and August the coldest of our four year survey period. The Bodrio del pastore III permanently hold water and, in 2014, its volume was larger and less fluctuating than in the past three years. Temperature and precipitations rise altered mixing regimes and seasonal variation of the Bodrio volume and represent major forcing on the abiotic and biotic factors accompanying interannual meteo-climatic variability. In general, the seasonal cycle of Daphnia depends on temperature and summer oxygen depletion (Alekseev, 2007). In accordance with general reports and with data from the Bodrio in the period 20112013, high Daphnia density population was recorded when temperature was between 15 and $22^{\circ} \mathrm{C}$ and, notwithstanding the reduction of mean temperature, a significant Daphnia population decline was recorded in late spring and early summer (Margaritora, 1985; Havel, 1985; Verbitskii et al., 2009; Rossi et al., 2014). In 2014, early seasonal peak of Daphnia was anticipated to late winter, a second late spring peak was recorded just before a sharp population decrease in June-August, and two further peaks were recorded in late August and early November. Peak abundance in November 2014 was higher than the maximum peak previously recorded in the cool June 2013 (Rossi et al., 2014). The shift in D. pulex population phenology, which seasonal growth started earlier and lasted

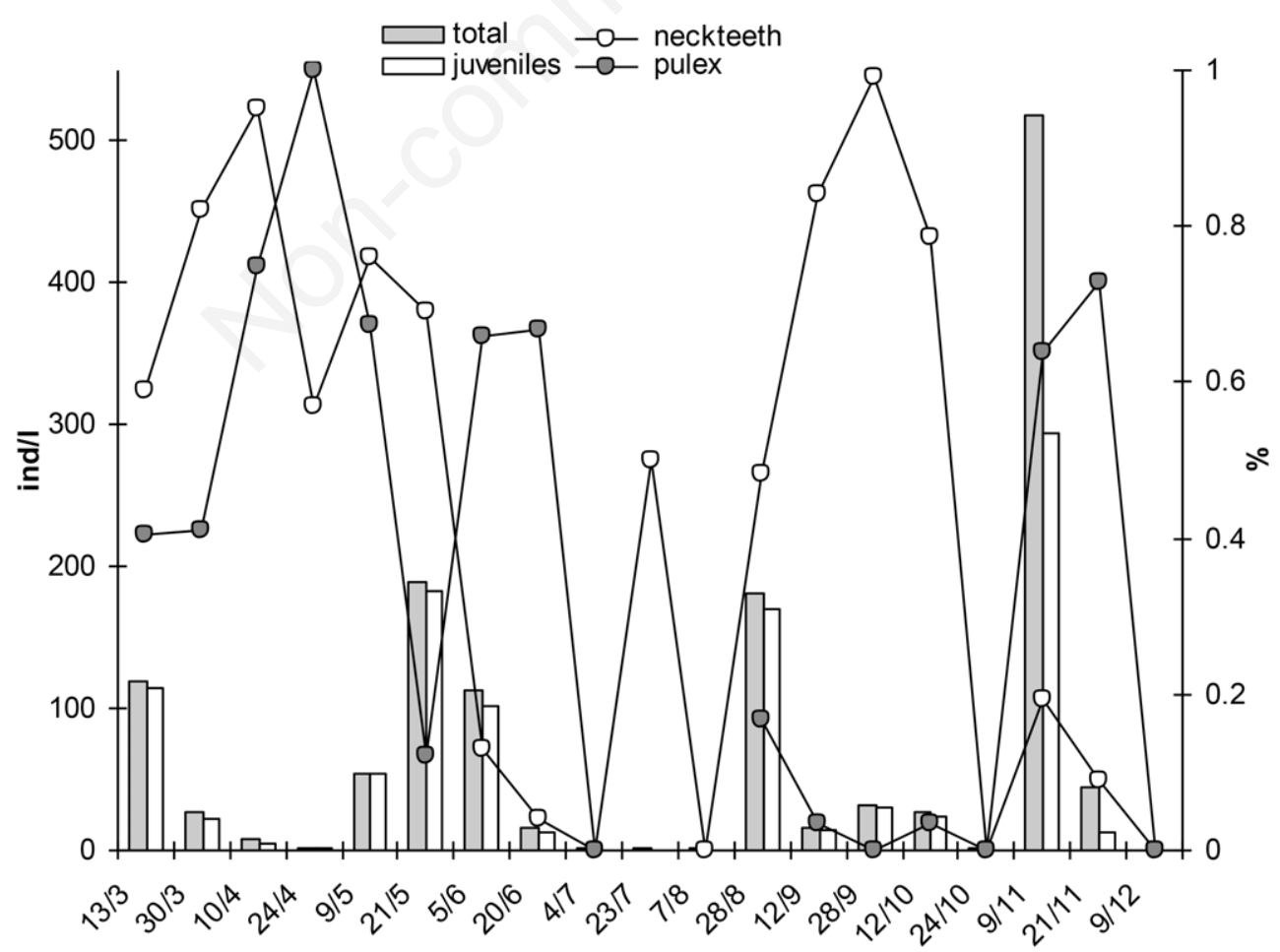

Fig. 3. Monthly variation of total density, juvenile density, neckteethed individuals percentage and D. pulex percentage in Daphnia population of the Bodrio del pastore III in 2014. 
longer, may be linked to a direct or indirect effect of winter temperature rise (Manca and DeMott, 2009; Manca, 2011; Manca et al., 2015). Warming may promote initial population growth by increasing fecundity per se and may be regarded as a factor able to worsen the effects of eutrophication (Schindler, 2001; Winder and Sommer, 2012). Peak density level may be positively correlated with increase of nutrient concentration and of food sources (Schalau et al., 2008; Manca et al., 2015). Hatching cues and associated emergence dynamics from resting stage have been given minor attention but winter warming may alter the interaction between photoperiod and temperature, and have direct, different effects on the emerging population of Daphnia (Vadadi-Fülöp and Hufnagel, 2014). In our case, earlier seasonal timing of Daphnia should be linked to cues for hatching of resting eggs (induced by late winter warming) (Chen and Folt, 2002; Gerten and Andrian, 2002). Shallow lakes of temperate areas has strong dependence on the resting egg-bank, as the probability of active overwintering daphnids decreases with lake depth (De Senerpont Domis et al., 2007; Dupuis and Hann, 2009). In D. catawba and Epischura lacustris from Norford Lake (Vermont, USA) spring thermal stress induced the early hatch of resting eggs (Chen and Folt, 2002). In 2014, autumnal unusual density peak of $D$. pulex was related to a delayed recruitment from ephippia that might be activated by anomalous thermal summer regime or by summer inundation due to the Bodrio largest volume (Stross, 1987; Rossi et al., 1998; Larsson, 1991; Clark et al., 2012).

A further and important anomaly with respect to the previous three years was the occurrence of $D$. longispina that, especially in September, accounts for the Daphnia population density peak and leads to a general increase of Daphnia in the Bodrio. The morphological re-examination of the stored zooplancton samples confirmed that $D$. longispina was not present in the Bodrio del pastore III in the period 2011-2013. Actually we found $D$. longispina in other two pools in the study area and we can assume that it came from there by recent dispersal, possibly linked to increased winter precipitation and subsequent floods (Rossi et al., in preparation). But we cannot rule out that $D$. longispina occurrence in 2014 was due to re-emergences from stored ephippia. In the second case we would highlight the common mechanism between the new record of D. longispina in the Bodrio and the anticipated and unusual autumnal recruitment of $D$. pulex from ephippia.

$D$. pulex and D. longispina have very similar ecological characteristics and interspecific differences in life history traits are dependent on temperature and food conditions (Hanski and Ranta, 1983). Their coexistence in rock pools was reported and shifts in competitive advantage with environmental changes were described (Bengtsson, 1986; 1987). In the Bodrio, D. pulex and $D$. longispina seasonal dynamics was quite different: $D$. longispina dominate in late summer while D. pulex

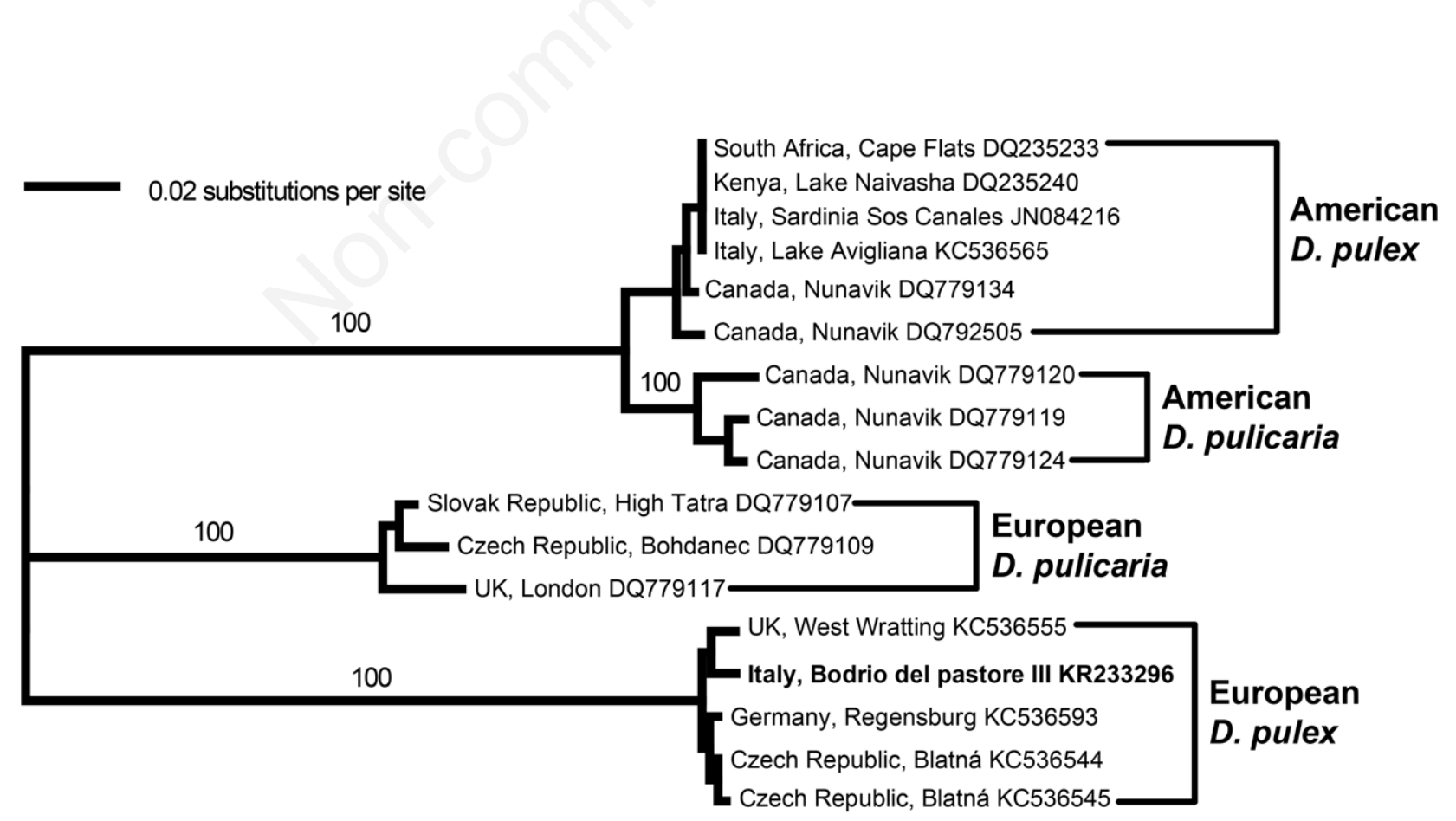

Fig. 4. A maximum likelihood (ML) phylogeny of ND5 sequences showing the relationship of haplotype carried by Daphnia from the Bodrio del pastore III with other members of the Daphnia pulex complex. Numbers along branches correspond to ML bootstrap support values if higher than 70 . 
showed the highest density in November. However morphological and genetic analysis confirmed the coexistence of both species in spring when the presence of epibionts on the postabdominal claw prevented a complete morphological discrimination of the two species and a reliable evaluation of their percentages. Epibionts were observed throughout the sampling period in 2014. The prevalence of infection increased from March to June, then epibionts changed anatomical units and were found mainly on the surface of carapace and on the antennae in autumn. We had not insight that infection degree was higher in $D$. pulex than in D. longispina or viceversa. The presence of epibionts on freshwater zooplankton is a very common phenomenon (Carman and Dobbs, 1997) and free swimming ciliates of the genus Carchesium were recorded in the Bodrio also in the previous study period. A high epibiont burden should indicate high food availability because the epibiont dispersal stage is actively and intensively grazed by Daphnia (Pérez-Martínez et al., 2001). Several studies have shown that virulence varies with temperatures and epibionts can influence zooplankton individual and population dynamics in many ways, although the available data show considerable variability (BareaArco et al., 2001; Mitchell et al., 2005).

In the Bodrio, both $D$. pulex and D. longispina reproduce by cyclical parthenogenesis but difference in sexual phase timing and importance between the two species was recorded. In 2014, as well as in 2011-2013 period, very early and continuous production of males and ephippia, also independent of population density, was observed in D. pulex (Rossi et al., 2014). A relatively limited investment in sexual reproduction and mismatch between the presence of males and ephippial females was recorded in D. longispina. Temperature, photoperiod, food availability (epibiont burden and/or edible phytoplankton biomass) were related to sexual reproduction: different threshold for males and ephippia production and both interspecific and intraspecific variation in sex allocation were reported (Stross, 1987; Hobaek and Larsson, 1990; Larsson 1991; Spaak 1995; Deng, 1996, Innes and Dunbrack, 1993; LaMontagne and McCauley, 2001; Slusarczyk 2001; Koch et al., 2009). We cannot exclude that the mismatch between males and ephippial females production in D. longispina might be an effect of the meteo-climatic anomaly (Yurista and O'Brien, 2001; Sarmaja-Korjonen, 2003; De Senerpont Domis et al., 2007; Lampert et al., 2012; Conde-Porcuna et al., 2013). According to our preliminary evaluation and due to the low density, C. flavicans should not affect Daphnia juvenile mortality or selective survivorship of the two different Daphnia species. However, Chaoborus larvae might account for seasonal variation of juvenile morphology in both Daphnia species. It is well known that, in presence of invertebrate predators $D$. pulex and D. longispina groups, developed neckteeth as inducible defences (Havel, 1985; Colbourne et al., 1997; Kotov et al., 2006; Juračka et al., 2011). Accordingly, we observed that the proportion of juveniles bearing neckteeth was a positive function of predator density and decreased in autumnal samples.

Finally, the finding of native European D. pulex strain in the Bodrio is important in the framework of conservation ecology. In this study we have showed that, to date, the Bodrio has not been colonized by the invasive North American asexual clone that has spread and replaced the native $D$. pulex throughout Africa, Spain and that has been recently recorded in Sardinia and Piedmont (Northern Italy) (Mergeay et al., 2006; Vergilino et al., 2011; Fadda et al., 2011; Crease et al., 2012; Marková et al., 2013).

\section{CONCLUSIONS}

Overall, our results suggest that coexistence of $D$. pulex and D. longispina, their biotic interactions, for instance with epibionts and predators, and/or shifts of their competitive advantage may depend on water temperature and hydroperiod. We do not claim that our present data prove a causality between weather and Daphnia dynamics anomaly in 2014 but we discuss about possible relationship between inter-annual meteo-climatic and Daphnia phenology variability. Our results encourage in continuing and extending our monitoring for evaluating direct and indirect impact of climate change on biological communities of shallow waters.

\section{ACKNOWLEDGMENTS}

The authors wish to thank R. Notarnicola for his assistance in Daphnia measurement and C. Cattabiani for manuscript revision. This study was financially supported by the University of Parma FIL 2013. Additional institutional support RVO 67985904 was provided to S. Marková and P. Kotlík.

\section{REFERENCES}

Alekseev VR, 2007. Diapause in crustaceans: peculiarity of induction, p. 29-63. In: V.R. Alekseev, B.T. De Stasio and J.J. Jilbert (eds.), Diapause in aquatic invertebrates: theory and human use. Springer, Amsterdam.

Barea-Arco J, Pérez-Martínez C, Morales-Baquero R, 2001. Evidence of a mutualistic relationship between an algal epibiont and its host, Daphnia pulicaria. Limnol. Oceanogr. 46:871-881.

Bengtsson J, 1986. Life histories and interspecific competition between three Daphnia species in rockpools. J. Anim. Ecol. 55:641-655.

Bengtsson J, 1987. Competitive dominance among Cladocera: are single-factor explanations enough? An examination of the experimental evidence. Hydrobiologia 145:245-257.

Carman KR, Dobbs FC, 1997. Epibiotic microorganisms on 
Copepods and other marine Crustaceans. Microsc. Res. Tech. 37:116-135.

Chen CY, Folt CL, 2002. Ecophysiological responses to warming events by two sympatric zooplankton species. J. Plankton Res. 24:579-589.

Clark MS, Denekamp NY, Mas T, Reinhardt R, Drungowski M, Albrecht MW, Klages S, Beck A, Kube M, Lubzens E, 2012. Long-term survival of hydrated resting eggs from $\mathrm{Bra}$ chionus plicatilis. PLoS ONE 7:e29365.

Colbourne JK, Hebert PDN, Taylor DJ, 1997. Evolutionary origins of phenotypic plasticity in Daphnia, p 163-188. In: T.J. Givnish and K.J. Sytsma (eds), Molecular evolution and adaptive radiation. Cambridge University Press.

Conde-Porcuna JM, Ramos-Rodríguez E, Pérez-Martínez C, 2013. In situ production of empty ephippia and resting eggs by an obligate parthenogenetic Daphnia population. J. Plankton Res. 36:157-169.

Crease TJ, Omilian AR, Costanzo KS, Taylor DJ, 2012. Transcontinental phylogeography of the Daphnia pulex species complex. PLoS ONE 7:e46620.

De Senerpont Domis LNW, Mooij M, Hülsmann S, Van Nes EH, Scheffer M, 2007. Can overwintering versus diapausing strategy in Daphnia determine match-mismatch events in zooplankton-algae interactions? Oecologia 150:682-698.

Deng HW, 1996. Environmental and genetic control of sexual reproduction in Daphnia. Heredity 76:449-458.

Dufresne F, Marková S, Vergilino R, Ventura M, Kotlík P, 2011. Diversity in the reproductive modes of European Daphnia pulicaria deviates from the geographical parthenogenesis. PLoS ONE 6:e20049.

Dupuis AP, Hann BJ, 2009. Climate change, diapause termination and zooplankton population dynamics: an experimental and modelling approach. Freshwater Biol. 54:221-235.

Edwards M, Richardson AJ, 2004. Impact of climate change on marine pelagic phenology and trophic mismatch. Nature 430:881-884.

Fadda A, Marková S, Kotlík P, Lugliè A, Padedda B, Buscarinu P, Sechi N, Manca M, 2011. First record of planktonic crustaceans in Sardinian reservoirs. Biologia 66:856-865.

Feuchtmayr H, Moran R, Hatton K, Connor L, Heyes T, Moss B, Harvey I, Atkinson D, 2009. Global warming and eutrophication: effects on water chemistry and autotrophic communities in experimental hypertrophic shallow lake mesocosms. J. Appl. Ecol. 46:713-723.

Gerten D, Adrian R, 2002. Species-specific changes in the phenology and peak abundance of freshwater copepods in response to warm summers. Freshwater Biol. 47:2163-2173.

Hanski I, Ranta E, 1983. Coexistence in a patchy environment: three species of Daphnia in rock pools. J. Anim. Ecol. 52:263-279.

Havel JE, 1985. Cyclomorphosis of Daphnia pulex spined morphs. Limnol. Oceanogr. 30:853-861.

Hays GC, Richardson AJ, Robinson C, 2005. Climate change and marine plankton. Trends Ecol. Evol. 20:337-344.

Hobaek A, Larsson P, 1990. Sex determination in Daphnia magna. Ecology 71:2255-2268.

Innes DJ, Dunbrack RL, 1993. Sex allocation variation in Daphnia pulex. J. Evol. Biol. 6:559-575.

Juračka PJ, Laforsch C, Petrusek A, 2011. Neckteeth formation in two species of the Daphnia curvirostris complex (Crus- tacea: Cladocera). In J. Seda and A. Petrusek (eds.) Daphnia as a model organism in limnology and aquatic biology: some aspects of its reproduction and development. J. Limnol. 70(Special Insert):359-368.

Koch U, von Elert E, Straile D, 2009. Food quality triggers the reproductive mode in the cyclical parthenogen Daphnia (Cladocera). Oecologia 159:317-24.

Kotov AA, Ishida S, Taylor DJ, 2006. A new species in the Daphnia curvirostris (Crustacea: Cladocera) complex from the eastern Palearctic with molecular phylogenetic evidence for the independent origin of neckteeth. J. Plankton Res. 28:1067-1079.

La Montagne JM, McCauley E, 2001. Maternal effects in Daphnia: what mothers are telling their offspring and do they listen? Ecol. Lett. 4:64-71.

Lampert W, Lampert KP, Larsson P, 2012. Induction of male production in clones of Daphnia pulex by the juvenoid hormone methyl farnesoate under short photoperiod. Comp. Biochem. Physiol. C 156:130-133.

Landkildehus F, Søndergaard M, Beklioglu M, Adrian R, Angeler DG, Hejzlar J, Papastergiadou E, Zingel P, Çakiroğlub AI, Scharfenberger U, Drakare S, Nõges T, Sorf M, Stefanidis K, Tavşanoğlu ÜN, Trigal C, Mahdy A, Papadaki C, Tuvikene L, Larsena SE., Kernan M, Jeppesen E, 2014. Climate change effects on shallow lakes: design and preliminary results of a cross-European climate gradient mesocosm experiment. Est. J. Ecol. 63:71-89.

Larsson P, 1991. Intraspecific variability in response to stimuli for male and ephippia formation in Daphnia pulex. Hydrobiologia 225:281-290.

Manca M, 2011. Invasion and re-emergences: an analysis of the success of Bythotrephes in Lago Maggiore (Italy). J. Limnol. 70:76-82.

Manca M, DeMott WR, 2009. Response of the invertebrate predator Bythotrephes to a climate-linked increase in the duration of a refuge from fish predation. Limnol. Oceanogr. 54:506-512.

Manca M, Rogora M, Salmaso N, 2015. Inter-annual climate variability and zooplankton: applying teleconnection indices to two deep subalpine lakes in Italy. J. Limnol. 74:123-132.

Margaritora GF, 1985. [Cladocera. Fauna d'Italia].[Book in Italian]. Calderini, Bologna: 389 pp.

Marková S, Dufresne F, Manca M, Kotlík P, 2013. Mitochondrial capture misleads about ecological speciation in the Daphnia pulex complex. PLoS ONE 8:e69497.

Marková S, Dufresne F, Rees DJ, Černý M, Kotlík P, 2007. Cryptic intercontinental colonization in water fleas Daphnia pulicaria inferred from phylogenetic analysis of mitochondrial DNA variation. Mol. Phylogenet. Evol. 44:42-52.

Meerhoff M, Clemente JM, Teixeira De Mello F, Iglesias C, Pederse AR, Jeppesen E, 2007. Can warm climate-related structure of littoral predator assemblies weaken the clear water state in shallow lakes? Glob. Change Biol. 13: 1888-1897.

Mergeay J, Verschuren D, De Meester L, 2006. Invasion of an asexual American water flea clone throughout Africa and rapid displacement of a native sibling species. Proc. R. Soc. B 273:2839-2844.

Mitchell SE, Rogers ES, Little TJ, Read AF, 2005. Host-parasite and genotype-by-environment interactions: temperature 
modifies potential for selection by a sterilizing pathogen. Evolution 59:70-80.

Pérez-Martínez C, Barea-Arco J, Sánchez-Castillo PM, 2001. Dispersal and colonization of the epibiont alga Korshikoviella gracilipes (Chlorophyceae) on Daphnia pulicaria (Cladocera). J. Phycol. 37:724-730.

Richardson AJ, 2008. In hot water: zooplankton and climate change. ICES J. Mar. Sci. 65:279-295.

Riessen HP, Linley RD, Altshuler I, Rabus M, Söllradl T, Clausen-Schaumann, Laforsch C, Yan ND, 2012. Changes in water chemistry can disable plankton prey defenses. P. Natl. Acad. Sci. USA 109:15377-15382.

Rossi V, Maurone C, Benassi G, Ferrari I, 2014. Reproduction of Daphnia pulex in a Northern Italy pond. J. Limnol. 73:459-467.

Rossi V, Rossetti G, Benatti M, Menozzi P, Ferrari I, 1998. Ephippial eggs and dynamics of the clonal structure of Daphnia longispina (Crustacea: Cladocera) in a mountain lake (Lago Scuro Parmense, Northern Italy). Ergeb. Limnol. 52:195-206.

Sarmaja-Korjonen K, 2003. Chydorid ephippia as indicators of environmental change biostratigraphical evidence from two lakes in southern Finland. Holocene 13:691-700.

Schalau K, Rinke K, Straile D, Peeters F, 2008. Temperature is the key factor explaining interannual variability of Daphnia development in spring: a modelling study. Oecologia 157:531-43.

Scheffer M, Straile D, van Nes EH, Hosper H, 2001. Climatic warming causes regime shifts in lake food webs. Limnol. Oceanogr. 46:1780-1783.

Schindler DW, 2001. The cumulative effects of climate warming and other human stresses on Canadian freshwaters in the new millennium. Can. J. Fish. Aquat. Sci. 58:18-29.

Slusarczyk M, 2001. Food threshold for diapause in Daphnia under the threat of fish predation. Ecology 82:1089-1096.
Spaak P, 1995. Sexual reproduction in Daphnia: interspecific differences in a hybrid species complex. Oecologia 4: 501-507.

Stross RG, 1987. Photoperiodism and phased growth in Daphnia population: coactions in perspective. In: R.H. Peters and de Bernardi R. (eds.), Daphnia. Mem Ist. Ital. Idrobiol. 45:413-437.

Tamura K, Stecher G, Peterson D, Filipski A, Kumar S, 2013. MEGA6: Molecular evolutionary genetics analysis, ver. 6.0. Mol. Biol. Evol. 30:2725-2729.

Vadadi-Fülöp C, Hufnagel L, 2014. Climate change and plankton phenology in freshwater: current trends and future commitments. J. Limnol. 73:1-16.

Vadadi-Fülöp C, Sipkay C, Mészáros G, Hufnagel L, 2012. Climate change and freshwater zooplankton: what does it boil down to? Aquat. Ecol. 46:501-519.

Verbitskii VB, Verbitskaya TI, Malysheva OA, 2009. Population dynamics of Daphnia longispina (O.F. Müller, 1785) and Diaphanosoma brachyurum (Lievin, 1848) (Crustacea, Cladocera) under stable and graded temperature regimes. Biol. Bull. 36:66-73.

Vergilino R, Marková S, Ventura M, Manca M, Dufresne F, 2011. Reticulate evolution of the Daphnia pulex complex as revealed by nuclear markers. Mol. Ecol. 20:1191-1207.

Visser ME, Both C, 2005. Shifts in phenology due to global climate change: the need for a yardstick. Proc. R. Soc. B 272:2561-2569.

Winder M, Schindler DE, 2004. Climate change uncouples trophic interactions in an aquatic ecosystem. Ecology 85:2100-2106.

Winder M, Sommer U, 2012. Phytoplankton response to a changing climate. Hydrobiologia 698:5-16.

Yurista PM, O'Brien WJ, 2001. Growth, survivorship and reproduction of Daphnia middendorffiana in several arctic lakes and ponds. J. Plankton Res. 23:733-744. 